\title{
The Effect of a Change in Wheat Prices on Incomes
}

\author{
MATEEN THOBANI*
}

The effect of an exogenous change in wheat prices on the welfare of farmers, middlemen, consumers and the government is analysed in a partial equilibrium framework under a wide range of elasticity assumptions. The resulting computer simulations yield the tradeoffs for various policies. Although pareto optimality calls for equating the consumer, producer and international prices, this policy cannot be followed with abandon because of its adverse effects on consumers.

\section{INTRODUCTION}

In Pakistan, the prices of most of the major agricultural crops are controlled. The government guarantees to procure wheat, rice, sugarcane and cotton at fixed prices. It is, therefore, very important to develop a theoretical framework which allows us to analyse the effects of changes in these prices on the production and consumption of the crops, and on the incomes of producers, consumers, middlemen and the government.

For example, the government has recently announced an increase in the procurement price of wheat, with a view to increasing its domestic production and lowering wheat imports. Some relevant questions may be raised. How does this affect the quantity of wheat marketed? Should the controlled price of wheat to the consumer be changed? By how much? Would this affect the price of wheat in the open market? How does the quantity of wheat sold in the open market vary with changes in the procurement price and consumer price? By how much does an increase in price lower its demand? What is its impact on imports of wheat? How are the incomes of farmers, middlemen, consumers and the government affected by changes in these price policies?

*The author, a graduate student at Yale University, was a Visiting Economist at the Applied Economics Research Centre, Karachi University, at the time the study was done. The study was funded by a grant from the Pakistan Agricultural Research Council, Islamabad. The author wishes to thank Akhtar Hai for his competent research assistance. He is particularly grateful to James Knowles and Hafiz Pasha for fruitful discussions and helpful comments on this paper and to Mahmud Hasan Khan and Michael Wallace for having initiated the effort. He is also thankful to the anonymous referees of the paper for their very useful comments and suggestions. However, the author alone is responsible for all remaining errors and omissions. 
In this paper, an attempt is made to answer quantitatively some of the questions raised above. A partial equilibrium approach is used which analyses the gains and losses in income from wheat price changes where the earnings and expenditure of wheat only are taken into consideration. It ignores the effect of raising the procurement price of wheat on the production of sugarcane, cotton or edible oils. This leaves some pertinent questions unanswered, but then they are beyond the scope of this paper. Are there net foreign exchange savings due to a decrease in wheat imports or are the savings from wheat offset by a rise in the imports of edible oils or by a decline in the exports of cotton? Are the additional profits to farmers from the higher farmgate price of wheat partially offset by a decrease in the profits due to lowered production of the other crops?

Despite the fact that this partial equilibrium approach ignores some important questions, it highlights some important links in the chain leading from a change in controlled prices to their effect on incomes, and enables us to obtain rough estimates of the gains and losses to various groups. A general equilibrium approach, which spells out demand and supply relationships for each of the major crops to yield a set of simultaneous equations, would require detailed data on prices and quantities of the major crops and on other exogenous variables (to identify the equations). These data, even if they exist, are very difficult to obtain.

A step towards removing some of the shortcomings of our approach is to consider cross elasticities of wheat with respect to other major crops. In this paper, no such attempt has been made due to two reasons. Firstly, reliable estimates of cross elasticities are even more difficult to obtain than those of own elasticities, and the alternative of doing further simulations would tax the readers' patience. Secondly, our results show that it is the change in exogenous price times quantity rather than the change in quantity times price which mainly accounts for the change in incomes. Thus the loss to farmers from a decreased production of other major crops would be small as compared to the gain to farmers from an exogenous change in the wheat price.

\section{THE WHEAT MARKET IN PAKISTAN}

Understanding the size and functioning of the wheat market is essential to an understanding of this paper. Last year's (May 1977 to April 1978) poor wheat crop is estimated at 8.1 million tons. Of this, about 7.3 million tons were available for consumption after due allowances for seeds and wastage. Imports for the current year are estimated to be 2.25 million tons. Making the assumption of uniform average yield on varying farm sizes, and estimating the marketable surplus on these farm sizes, we can arrive at an estimate of the quantity of wheat marketed - about 2.8 million tons [see Appendix I]

The government sets a price at which it stipulates to procure wheat from farmers. This price is currently Rs. $37 /$ maund ( 1 maund $=37.32$ kilograms). From last year's wheat crop, the government has bought an estimated 1.1 million tons. The remainder of the marketable surplus ( 1.7 million tons) was sold in the open market by arhtis (middlemen). Before being sold in the open market, the wheat was processed to yield good quality flour and was then sold at an average price of Rs. 57/maund.

The wheat sold to the government is, on the average, of a slightly inferior quality. It is mixed with imported wheat and sold to flour mills at Rs. 32/maund (issue price). The wheat is processed and sold by the government ration shops to the consumer at Rs. 36/maund. The fact that consumers are willing to pay Rs. 57/maund for essentially the same product in terms of nutritional value is due to a difference in quality. The ration shop wheat does not make good white chapatis (thin, flat cakes of coarse unleavened bread) because it contains imported wheat which has different characteristics. Thus there are essentially two grades of wheat on the demand side which are treated as different commodities -- one sold in the ration shops and the other in the open market. On the supply side, however, there is only one type of wheat that is sold either to the government or to arhtis (middlemen).

In a survey conducted by a management consulting firm, the following reasons were given for farmers' preferences for selling wheat to the arhtis as opposed to the government.

The farmers who expressed preference for selling to the arthi stated that this was so because the arthi comes to buy the wheat (37\%) makes on-the-spot cash payment $(30 \%)$, sometimes advances loans $(27 \%)$, is honest in weighing, is available whenever needed, supplied gunny bags and maintains a continuing relationship with the farmer [1].

On the other hand, the following reasons were given for farmers' preferences for selling wheat to the government as opposed to the arhtis:

Those farmers who preferred to sell directly to the purchase centre stated that they preferred to receive cash payment (48\%), did not bear any risks in payments $(30 \%)$ and did not have to pay a commission to the arthi $(23 \%)$. They were satisfied with weighing at the centre, and did not face other problems.

The reasons given by both sets of farmers are similar and appear to be based on individual farmer conditions rather than on a consistent real price bias either way. Since farmers are free to sell to the government or the middleman, the middleman must pay the same real price as the government. Thus the farmgate price or price paid by the arhti must equal the procurement price.

Some farmers sell wheat to the arhtis who later sell it to the government. Since the wheat eventually reaches the government and ration shops, it is treated as if the farmer had sold it directly to the government. The reader may well ask what the incentive is for the arhti to buy and sell at the same price. Actually the arhti will often be able to buy wheat at a slightly lower price (Rs. 34) from farmers to whom 
there is at least a Rs. 3 transactions cost (transportation, time, etc.) in selling to the government. The transactions cost to the arhti would be lower and hence he could make a small profit. This small profit to the middleman is ignored in the analysis and the wheat is treated exactly as if it had been sold directly to the government. Note that the real procurement price, although lower than Rs. 37 , is still equal to the farmgate price.

In addition, there' are farmers who store wheat and later sell it in the open market towards pre-harvest time at a higher price. The farmer then plays the role of both farmer and middleman. The additional income which accrues to the farmer in his role as middleman is treated as such and included in the gains or losses to middlemen.

Some integration between the open market and the government-controlled market is assumed in this paper. More specifically, it is assumed that a change in price in one market affects the quantity demanded in the other market. A black market for ration shop wheat is avoided because the government either draws on its stocks or imports additional amounts to compensate for any pressure on the ration shop price.

\section{METHODOLOGY}

There are two instruments in our model: the procurement price, $\mathrm{P}_{\mathrm{p}}$, and the issue price, $P_{g}$, which are, respectively, the price at which the government buys wheat from the farmer, and the price at which it sells to the mills. First an increase in the procurement price, holding the issue price constant, is considered. The effect of this change on the incomes of farmers, middlemen, consumers and the government is examined in turn. The government has already announced the procurement price increase to Rs. $45 /$ maund and farmers have made their production decisions. It is instructive to measure the gains and losses to our interest groups caused by this announcement. Then, the effect on incomes of raising issue price is considered, assuming that the procurement price is held constant. This is a useful exercise in itself but is all the more important because the government is considering an increase in consumer price. For obvious reasons (the price has already been raised), the initial level of the procurement price for the second exercise will be taken to be Rs. $45 /$ maund. Thus the paper can be considered as looking at two sets of policies: (i) increase only the procurement price; and (ii) increase the procurement price along with the issue price. The interested reader can note that it would not be too difficult to incorporate changes in the controlled prices of inputs (e.g. fertilizer) into the analysis.

This exercise quantifies the change in incomes due to this policy and looks at the effect on incomes if the issue price is also raised. The latter serves to decrease the subsidy bill on wheat by not only reducing the per unit subsidy but by decreasing total consumption.
One of three different concepts of income has been used as appropriate for each of the four groups of people. For farmers and middlemen, it is the change in profit levels. For consumers, it is the change in consumer surplus, ${ }^{1}$ while for the government, it is the change in revenues. Throughout, it is assumed that the four groups of people are mutually exclusive.

Since reliable estimates for the values of some of the parameters used in this analysis are not available, a computer simulation exercise is carried out for various parameter values. The justification for not trying harder to obtain estimates for the parameters is that the results are not very sensitive to changes in these parameters within plausible ranges.

A list of the notation employed in this analysis is given at the end of the paper for reference. ${ }^{2}$

\section{Increase the Procurement Price by $\Delta \mathbf{P}_{\mathbf{p}}$} (a) Effect on Farmers' Incomes

In Fig. 1(a), SS is the aggregate supply curve for wheat. At farmgate price, $P_{p}$ (equal to procurement price), $Q_{p}$ is produced. Of this, $Q_{f}$ is kept for own consumption by farmers, based on their demand curve, DD. $\mathrm{Q}_{\mathrm{f}}$ includes wheat for home consumption, seeds, wastage, and payment to workers in kind.

For simplification, it is assumed that in the case of home consumption of wheat by farmers, the positive income effect of an increase in farmgate price is exactly offset by the negative substitution effect so that $Q_{f}$ is fixed for a relevant range of farmgate prices.

This is illustrated in Fig. 1(b) where $D_{1} D_{1}$ is the demand curve for wheat by farmers at income $Y_{1}$. Income is a positive function of price. When the price is raised to $\mathrm{P}_{2}$, it increases the income of the farmer to $\mathrm{Y}_{2}$ to yield a new demand curve, $D_{2} D_{2}$, which coincidentally intersects a vertical line through $Q_{f}$. Similarly, $D_{3} D_{3}$ and $\mathrm{D}_{4} \mathrm{D}_{4}$, yield the same consumption of wheat at prices $\mathrm{P}_{3}$ and $\mathrm{P}_{4}$, respectively. By making use of this simplification, we can treat the portion of SS to the right of $Q_{f}$ as both the marketable surplus curve and the marginal cost curve. Several studies [e.g. 2] on Pakistan have shown the curve to be positively sloped.

Fig. 1(c) is Fig. 1(a) redrawn to shift the origin to $Q_{\mathrm{f}}$. In Fig. 1(c), at a price $P_{p}$, farmers are willing to supply a quantity $Q_{p}$ to be marketed. $P_{p}$ is the procurement price, which, under our earlier assumption, is also the price at which farmers sell to middlemen who sell in the open market. When the procurement price

${ }^{1}$ This concept, often used to measure consumer welfare, is the area under the demand curve and above the price line. Since the demand curve represents the price a consumer is willing to pay while the price line denotes the price he pays, the difference represents a surplus that he enjoys.

${ }^{2}$ Please also note the convention used here of assuming all $\Delta s$ to be positive. Decreases and negative expressions are preceded by a negative sign or prefaced by the word loss or decrease. 


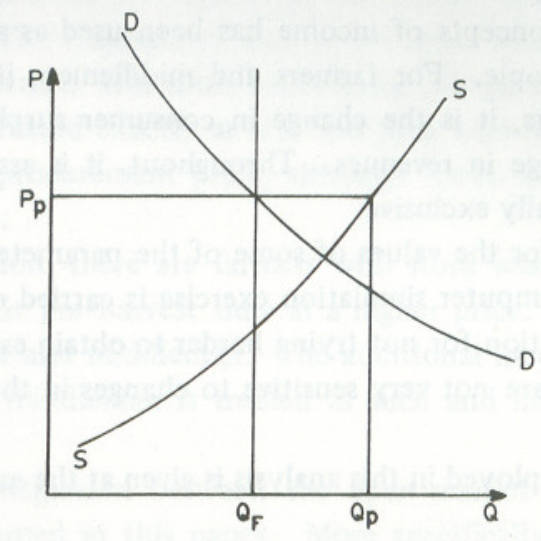

(a)

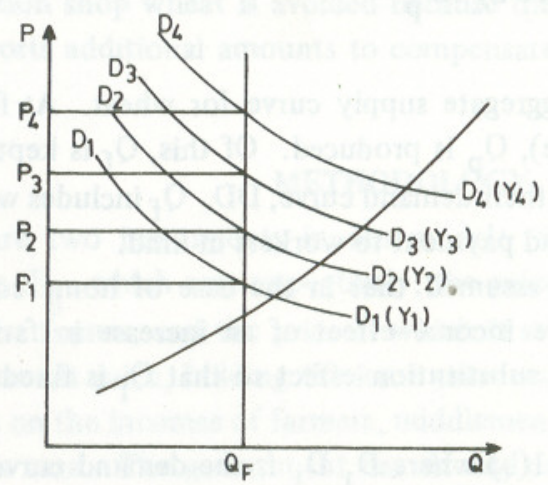

(b)

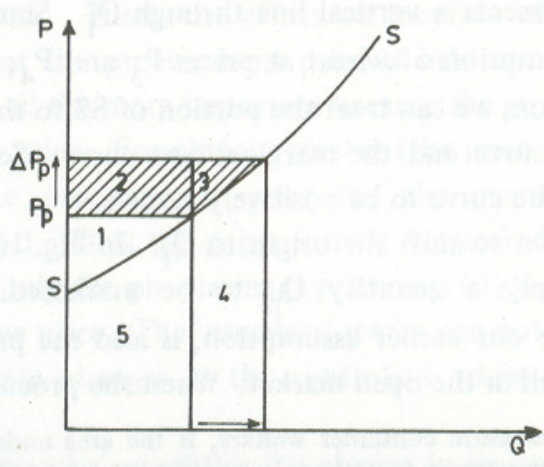

is raised by $\Delta \mathrm{P}_{\mathrm{p}}$, middlemen who wish to sell in the open market must also offer a price $\mathrm{P}_{\mathrm{p}}+\Delta \mathrm{P}_{\mathrm{p}}$. Farmers increase their production by $\Delta \mathrm{Q}_{\mathrm{p}}$ due to a combination of increased acreage used in wheat and higher yields because it is now profitable to buy a larger quantity of fertilizer per acre, or obtain improved seeds and water facilities. The elasticity of marketable surplus, $e^{\mathrm{s}}$, which measures the responsiveness of a change in farmgate price to a change in wheat marketed, is an aggregate of the acreage effect, the yield effect and the income effect. The increase in profits is given by the area $2+3$, the difference between increased revenues by $2+3+4$, and increased costs by 4 .

The magnitude of area 2 is $Q_{p} \Delta P_{p}$. We can approximate area 3 by assuming that the segment of the supply curve between $Q_{p}$ and $Q_{p}+\Delta Q_{p}$ is linear. This area is then $1 / 2 \Delta P_{p} \Delta Q_{p}$. The total increase in profits for farmers is given by

$$
\mathrm{Q}_{\mathrm{p}} \Delta \mathrm{P}_{\mathrm{p}}+1 / 2 \Delta \mathrm{P}_{\mathrm{p}} \Delta \mathrm{Q}_{\mathrm{p}} \quad \quad \ldots \quad \ldots \quad \ldots \quad \ldots
$$

where $\Delta Q_{p}=e^{s} Q_{p} \Delta P_{p} / P_{p}$, and $e^{s}$ is the elasticity of marketable surplus.

\section{(b) Effect on Middlemen's Incomes}

In Fig. 2, DD is the demand curve for open market wheat and RR the corresponding marginal revenue curve. Initially, the middlemen can buy wheat at a price $P_{p}$ up to a level of output $Q_{p}$. After this point, they have to buy along the supply curve TT'MC. The marginal cost curve is given by STT'MC. The profit maximizing monopolist buys a quantity $Q_{0}$ where his marginal cost equals marginal reven $\iota$, and charges a price $P_{0}$. His profit is given by $\left(P_{0}-P_{p}\right) Q_{0}$.

When the procurement price is raised by $\Delta \mathrm{P}_{\mathrm{p}}$, the middlemen have to pay $\Delta \mathrm{P}_{\mathrm{p}}$ more for the wheat they buy from farmers. The new marginal cost is given by $\mathrm{S}^{\prime} \mathrm{T}^{\prime} \mathrm{MC}$, and, because of the higher price $\mathrm{P}_{\mathrm{O}}+\Delta \mathrm{P}_{\mathrm{O}}$, the amount of wheat bought in the open market reduces by $\Delta Q_{0}$. The new profit is given by

$$
\left(\mathrm{P}_{\mathrm{o}}+\Delta \mathrm{P}_{\mathrm{o}}-\mathrm{P}_{\mathrm{p}}-\Delta \mathrm{P}_{\mathrm{p}}\right)\left(\mathrm{Q}_{\mathrm{o}}-\Delta \mathrm{Q}_{\mathrm{o}}\right)
$$

The loss is, therefore,

$$
\left(\mathrm{P}_{\mathrm{o}}-\mathrm{P}_{\mathrm{p}}\right) \Delta \mathrm{Q}_{\mathrm{o}}+\left(\Delta \mathrm{P}_{\mathrm{p}}-\Delta \mathrm{P}_{\mathrm{o}}\right)\left(\mathrm{Q}_{\mathrm{o}}-\Delta \mathrm{Q}_{\mathrm{o}}\right)
$$$$
\text { . }
$$

Some points are worth noting here.

Middlemen involved in every level from milling to retailing are being lumped together and treated as one monopolistic middleman. This behavioural assumption allows us to determine the levels of price and quantity of wheat in the open market after the price change. In a sense, it tells us the best that the middlemen can do if they act in collusion and the most that they can pass on in higher prices to the 


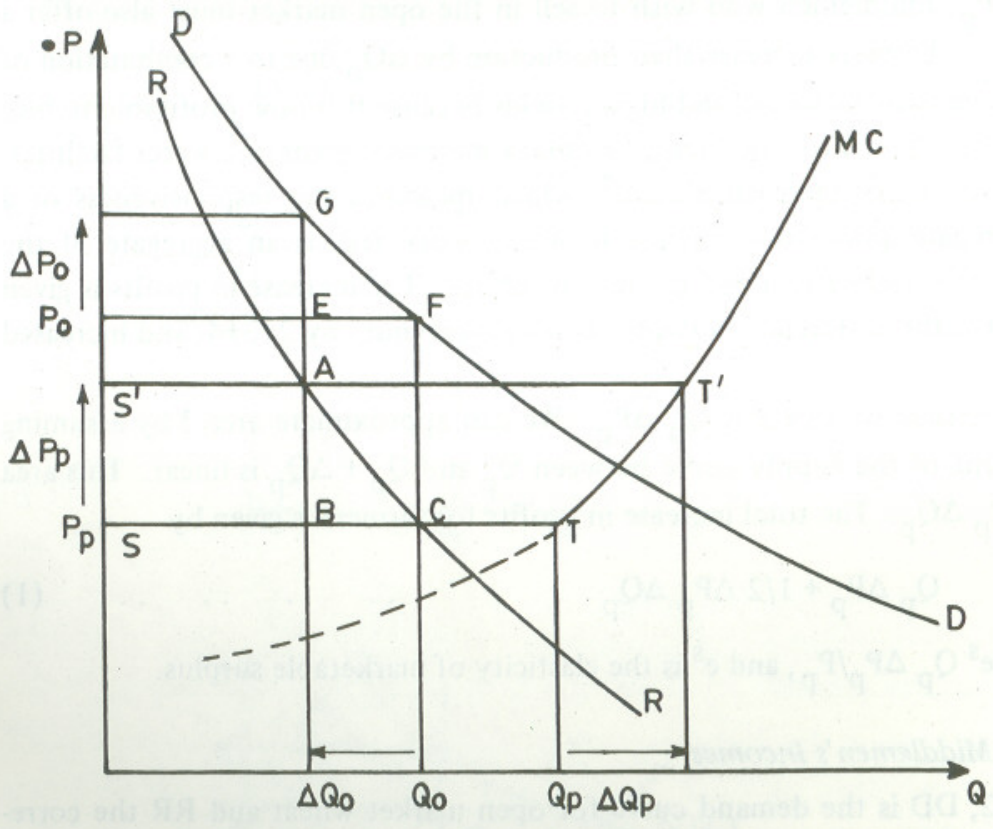

Fig.2. Increasing $P_{p}$ - The Open Market

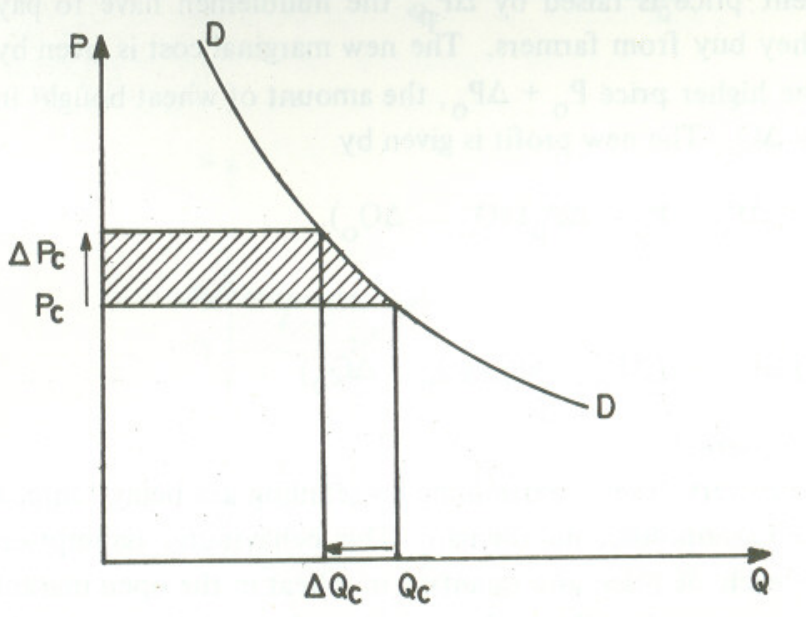

Fig.3. Increasing $P_{p}$ - The Ration Shop open market consumer. It is instructive to note that even in this case the most that the middlemen can pass on in higher prices to the consumer is half the increase in procurement price and that middlemen must necessarily lose by the increase in procurement price. The first part of the proposition is proved in Appendix II. To verify the latter part, consider expression (2) above. Since $\Delta \mathrm{P}_{\mathrm{p}}=2 \Delta \mathrm{P}_{\mathrm{o}}$ and $\Delta \mathrm{Q}_{\mathrm{O}}<\mathrm{Q}_{\mathrm{O}}$, every term in the loss expression is positive.

\section{(c) Effect on Consumers' Incomes}

In Fig. 2, at the procurement price $P_{p}$, middlemen sell at $P_{o}$ in the open market. The surplus enjoyed by the open market consumer is then the area under DD and above $\mathrm{P}_{\mathrm{o}}$. With an increase in $\mathrm{P}_{\mathrm{p}}$ of $\Delta \mathrm{P}_{\mathrm{p}}$, the price $\mathrm{P}_{\mathrm{o}}$ rises by $\Delta \mathrm{P}_{\mathrm{o}}$ resulting in a smaller consumer surplus. The change in consumer surplus is the sum of area 1 and area 2 which can be approximated by the expression

$$
\Delta \mathrm{P}_{\mathrm{O}}\left(\mathrm{Q}_{\mathrm{O}}-\Delta \mathrm{Q}_{\mathrm{O}}\right)+1 / 2 \Delta \mathrm{P}_{\mathrm{o}} \Delta \mathrm{Q}_{\mathrm{O}} \quad \ldots \quad \ldots
$$

where $\Delta \mathrm{Q}_{\mathrm{O}}=\mathrm{e}_{\mathrm{O}}^{\mathrm{d}} \frac{\Delta \mathrm{P}_{\mathrm{o}}}{\mathrm{P}_{\mathrm{O}}} \mathrm{Q}_{\mathrm{O}}$ by definition,

$e_{0}^{d}=$ the demand elasticity of open market wheat, and

$\Delta \mathrm{P}_{\mathrm{O}}=1 / 2 \Delta \mathrm{P}_{\mathrm{p}}$ from Appendix II.

If there is some interaction between the open market and the government market, there will be a small increase in the surplus of ration shop consumers. The increased procurement price induces an increase in the open market retail price as described earlier. The relative higher price makes consumers switch to ration shop wheat. Since the price in the government market has not changed, the excess demand pressure on ration shop wheat must result in a lowering of government wheat stocks or in increased imports ${ }^{3}$ and, consequently, in a larger consumer surplus. However, since this effect is tertiary and is negligible as compared with the consumer loss in the open market, it is ignored in this section. The integration of the two markets is incorporated in the next part when the effect is more direct.

\section{(d) The Effect on Government Income}

The government subsidy on wheat, excluding distribution and storage costs, before the price increase is given by the sum of subsidies on domestic and imported wheat.

${ }^{3}$ Government wheat stocks and/or imports will be higher where there is no integration between the markets and the procurement price is raised. Note that an increase in government wheat demand must be less than the decrease in open market demand if wheat is a normal good because of the negative income effect of a constant ration shop price and a higher open market price. 


$$
\left(P_{p}-P_{g}\right) Q_{g}+\left(P_{i}-P_{g}\right) Q_{i}
$$

where $Q_{g}$ is the amount of wheat that the government procures from farmers,

$\mathrm{Q}_{\mathrm{i}}$ is the quantity of imported wheat, and

$\mathrm{P}_{\mathrm{i}}$ is the import price excluding storage and distribution costs.

The increase in procurement price causes the per unit subsidy to increase and results in a larger quantity of wheat offered to the government. The latter is the sum of two effects: (i) the production of wheat increases from the increased farmgate price as described earlier; and (ii) the increased procurement price induces an increase in open market price which leads to a reduction in the quantity of wheat demanded in the open market. The wheat that would have been sold in the open market is then sold to the government in addition to the entire increase in marketed surplus. Therefore, the government purchases an additional amount $\Delta \mathrm{Q}_{\mathrm{g}}$, given by the expression:

$$
\mathrm{e}^{\mathrm{s}} \frac{\Delta \mathrm{P}_{\mathrm{p}}}{\mathrm{P}_{\mathrm{p}}} \mathrm{Q}_{\mathrm{g}}+\mathrm{e}_{\mathrm{o}}^{\mathrm{d}} \frac{\Delta \mathrm{P}_{\mathrm{o}}}{\mathrm{P}_{\mathrm{o}}} \mathrm{Q}_{\mathrm{O}}
$$

The quantity of imported wheat must decrease by the same amount since the ration shop price has not changed. The total demand for wheat has fallen by the second term above while the total supply has increased by the first term in the above expression. ${ }^{4}$

The subsidy after the price increase is given by

$$
\left(P_{p}+\Delta P_{p}-P_{g}\right)\left(Q_{g}+\Delta Q_{g}\right)+\left(P_{i}-P_{g}\right)\left(Q_{i}-\Delta Q_{g}\right) \quad \ldots
$$

Subtracting (4) from (5) we get the increase in subsidy to be ${ }^{5}$

$$
\left(\mathrm{Q}_{\mathrm{g}}+\Delta \mathrm{Q}_{\mathrm{g}}\right) \Delta \mathrm{P}_{\mathrm{p}}-\left(\mathrm{P}_{\mathrm{i}}-\mathrm{P}_{\mathrm{p}}\right) \Delta \mathrm{Q}_{\mathrm{g}}
$$

which is positive for all plausible values of $\mathrm{e}^{\mathrm{s}}$ and $\mathrm{e}_{\mathrm{O}}^{\mathrm{d}}$.

\section{Increase the Issue Price by $\Delta \mathbf{P}_{\mathbf{g}}$}

It is assumed that this results in an increase of $\Delta P_{g}$ in the retail ration shop price $\mathrm{P}_{\mathrm{c}}$. In other words, raising $\mathrm{P}_{\mathrm{g}}$ from Rs. 32 to Rs. $34 /$ maund increases the retail ration shop price from Rs. 36 to Rs. 38/maund - a plausible approximation.

${ }^{4}$ Actually the total demand will have fallen by a little less than the second term due to a small switch-over effect to ration shop wheat. Again, since this effect is small, it is ignored.

${ }^{5}$ Ignoring distribution costs is justifiable since the costs of distribution of both domestic and imported wheat are about the same, and we are concerned with changes in subsidies, not the absolute levels.

\section{(a) Effect on Farmers' Incomes}

The increased ration shop price does not bring about any change in the price paid to farmers or the quantity of wheat supplied. The lowered demand for wheat will be offset by a corresponding decrease in imports leaving domestic production unchanged. Therefore, this policy does not bring about any change in farmers' incomes.

\section{(b) Effect on Middlemen's Incomes}

If the ration shop wheat market and the open wheat market are assumed to be completely independent of each other, there is no change in middlemen incomes. However, since the two types of wheat are substitutes, raising the price of wheat in one market is likely to shift the demand curve for open market wheat outward, thereby increasing both the open market price and the quantity demanded as shown in Fig. 4. The increase in profits shown by the shaded area is given by

$$
P_{0} Q_{0}+\Delta Q_{0}\left(P_{o}+\Delta P_{o}-P_{p}\right) \quad \ldots \quad \ldots \quad \ldots \quad \ldots
$$

where $\Delta \mathrm{P}_{\mathrm{O}}$ and $\Delta \mathrm{Q}_{\mathrm{O}}$, from Appendix III, are given by $\frac{\mathrm{e}_{\mathrm{c}}^{\mathrm{d}} \Delta \mathrm{P}_{\mathrm{c}}}{2 \mathrm{e}_{\mathrm{O}}^{\mathrm{d}} \mathrm{P}_{\mathrm{c}}} \mathrm{P}_{\mathrm{o}}$ and $\frac{\mathrm{e}_{\mathrm{c}}^{\mathrm{d}} \Delta \mathrm{P}_{\mathrm{c}}}{2 \mathrm{P}_{\mathrm{c}}} \mathrm{Q}_{\mathrm{O}}$
respectively.

\section{(c) Effect on Consumers' Incomes}

(i) From Fig. 3 we can readily quantify the loss in consumer surplus of ration shop consumers as:

$$
\Delta P_{c}\left(Q_{c}-\Delta Q_{c}\right)+1 / 2 \Delta P_{c} \Delta Q_{c} \quad \ldots \quad \ldots \quad \ldots \quad \ldots
$$

where $\Delta \mathrm{Q}_{\mathrm{c}}=\mathrm{e}_{\mathrm{r}}^{\mathrm{d}} \frac{\Delta \mathrm{P}_{\mathrm{c}}}{\mathrm{P}_{\mathrm{c}}} \mathrm{Q}_{\mathrm{c}}$

(ii) The open market consumers face a higher price but purchase a larger quantity of wheat. The consumer surplus decreases because of the increased price but increases from the larger quantity consumed. The simulations show that both these effects are small and act in opposite directions which allows us to ignore them.

\section{(d) Effect on Government Income}

As expected, the government gains significantly from this policy. The subsidy incurred by the government before the price increase is as in expression (4) in the last part.

The price increase results in a decline in the wheat demanded in the ration shops $\left(\Delta \mathrm{Q}_{\mathrm{c}}\right)$ and a small increase in the quantity demanded in the open market 


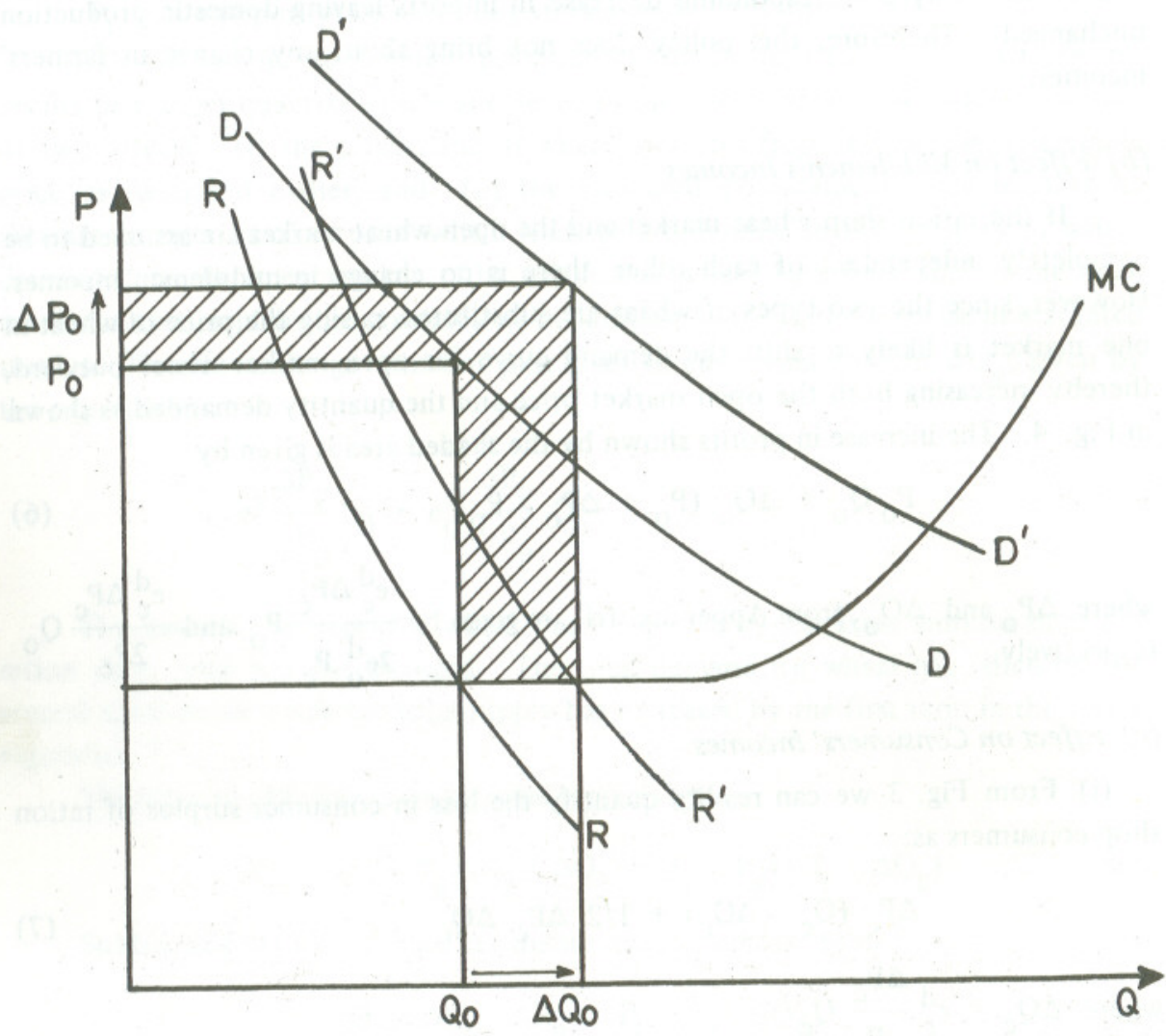

Fig. 4. Increasing $P_{c}-$ The Open Market
$\left(\Delta \mathrm{Q}_{\mathrm{O}}\right)$ because of the cross elasticity effect. The increased demand for wheat in the open market causes middlemen to buy greater amounts from farmers leaving less for government procurement. Imports of wheat decrease by an amount equal to the difference between $\Delta \mathrm{Q}_{\mathrm{c}}$ and $\Delta \mathrm{Q}_{\mathrm{O}}$. The new subsidy is given by

$$
\left(P_{p}-P_{g}-\Delta P_{g}\right)\left(Q_{g}-\Delta Q_{g}\right)+\left(P_{i}-P_{g}-\Delta P_{g}\right)\left(Q_{i}-\Delta Q_{i}\right) \quad \ldots
$$

where $\Delta Q_{g}=\Delta Q_{0}=\frac{e_{c}^{d} \Delta P_{c} Q_{o}}{2 P_{c}}$,

$$
\begin{aligned}
& \Delta \mathrm{Q}_{\mathrm{c}}=\mathrm{e}_{\mathrm{r}}^{\mathrm{d}} \frac{\Delta \mathrm{P}_{\mathrm{c}} \Delta \mathrm{Q}_{\mathrm{c}}}{\mathrm{P}_{\mathrm{c}}} \text {, and } \\
& \Delta \mathrm{Q}_{\mathrm{i}}=\Delta \mathrm{Q}_{\mathrm{c}}-\Delta \mathrm{Q}_{\mathrm{o}}
\end{aligned}
$$

Subtracting (8) from (4) and substituting for $Q_{g}$ and $Q_{i}$ we get the increase in goyernment income:

$$
\left(\mathrm{Q}_{\mathrm{i}}+\mathrm{Q}_{\mathrm{g}}\right) \Delta \mathrm{P}_{\mathrm{g}}+\left(\mathrm{P}_{\mathrm{i}}-\mathrm{P}_{\mathrm{g}}-\Delta \mathrm{P}_{\mathrm{g}}\right) \Delta \mathrm{Q}_{\mathrm{c}}-\left(\mathrm{P}_{\mathrm{i}}-\mathrm{P}_{\mathrm{p}}\right) \Delta \mathrm{Q}_{\mathrm{o}}
$$

\section{RESULTS}

The results of the above exercise are displayed in Tables 1 and 2. Table 1 quantifies the change in incomes of the four groups for varying elasticity estimates. The range used for the elasticity of marketable surplus of between 0.0 and 0.7 . is based on a range of 0.3 to 0.7 estimated by Qureshi [2] and an extreme value of zero suggested by some pessimists. Ranges for other elasticities were more arbitrarily chosen, based on the author's perceptions. Fortunately most of the results are not very sensitive to the various assumptions. This is due to the fact that although the range of elasticities is large, the absolute value of the elasticity is still small. It is the change in the exogenous price times the quantity rather than the change in quantity times the price which accounts for most of the variation in incomes.

The first rows of both Table 1 and Table 2 are based on the "most likely" set of assumptions in the author's view. Table 2 shows the sensitivity in results for changes in some of the variables about whose initial values there was some doubt. Again, the results were encouraging in that they were not very sensitive to relatively large changes in the variables.

Several points are worth noting.

(i) Since the four groups of people are mutually exclusive, a Rs. 640 million gain to farmers from the increase in procurement price is not the net gain but the gain due to his role as a farmer. A typical farmer will also lose a small amount in so 


\begin{tabular}{|c|c|c|c|c|c|c|c|c|}
\hline \multirow{2}{*}{ Assumptions* } & \multicolumn{4}{|c|}{ Farmers } & \multicolumn{4}{|c|}{ Middlemen } \\
\hline & $\Delta \mathrm{P}_{\mathrm{p}}=8$ & $\Delta \mathrm{P}_{\mathrm{g}}=2$ & $\Delta \mathrm{P}_{\mathrm{g}}=4$ & $\Delta P_{g}=6$ & $\Delta \mathrm{P}_{\mathrm{p}}=8$ & $\Delta \mathrm{P}_{\mathrm{g}}=2$ & $\Delta P_{g}=4$ & $\Delta P_{g}=6$ \\
\hline Basic Run & & & & & & & & \\
\hline $\begin{array}{ll}\mathrm{e}^{\mathrm{s}}=.4 & \mathrm{e}_{\mathrm{r}}^{\mathrm{d}}=.2 \\
\mathrm{e}_{\mathrm{o}}^{\mathrm{d}}=.4 & \mathrm{e}_{\mathrm{c}}^{\mathrm{d}}=.2\end{array}$ & 641.8 & 641.8 & 641.8 & 641.8 & -208.9 & -166.0 & -122.6 & -78.8 \\
\hline Varying $e^{S}$ & & & & & & & & \\
\hline $\begin{array}{ll}\mathrm{e}^{\mathrm{s}}=.0 & \mathrm{e}_{\mathrm{r}}^{\mathrm{d}}=.2 \\
\mathrm{e}_{\mathrm{o}}^{\mathrm{d}}=.4 & \mathrm{e}_{\mathrm{c}}^{\mathrm{d}}=.2\end{array}$ & 615.2 & 615.2 & 615.2 & 615.2 & -208.9 & -166.0 & -122.6 & -78.8 \\
\hline $\begin{array}{ll}\mathrm{e}^{\mathrm{s}}=.1 & \mathrm{e}_{\mathrm{r}}^{\mathrm{d}}=.2 \\
\mathrm{e}_{\mathrm{o}}^{\mathrm{d}}=.4 & \mathrm{e}_{\mathrm{c}}^{\mathrm{d}}=.2\end{array}$ & 621.8 & 621.8 & 621.8 & 621.8 & -208.9 & -166.0 & -122.6 & -78.8 \\
\hline $\begin{array}{ll}\mathrm{e}^{\mathrm{s}}=.2 & \mathrm{e}_{\mathrm{r}}^{\mathrm{d}}=.2 \\
\mathrm{e}_{\mathrm{o}}^{\mathrm{d}}=.4 & \mathrm{e}_{\mathrm{c}}^{\mathrm{d}}=.2\end{array}$ & 628.5 & 628.5 & 628.5 & 628.5 & -208.9 & -166.0 & -122.6 & -78.8 \\
\hline $\begin{array}{ll}\mathrm{e}^{\mathrm{s}}=.3 & \mathrm{e}_{\mathrm{r}}^{\mathrm{d}}=.2 \\
\mathrm{e}_{\mathrm{o}}^{\mathrm{d}}=.4 & \mathrm{e}_{\mathrm{c}}^{\mathrm{d}}=.2\end{array}$ & 635.1 & 635.1 & 635.1 & 635.1 & -208.9 & -166.0 & -122.6 & -78.8 \\
\hline
\end{tabular}

Table 1-A-Continued

\begin{tabular}{|c|c|c|c|c|c|c|c|c|}
\hline $\begin{array}{ll}\mathrm{e}^{\mathrm{s}}=.5 & \mathrm{e}_{\mathrm{r}}^{\mathrm{d}}=.2 \\
\mathrm{e}_{\mathrm{o}}^{\mathrm{d}}=.4 & \mathrm{e}_{\mathrm{c}}^{\mathrm{d}}=.2\end{array}$ & 648.4 & 648.4 & 648.4 & 648.4 & -208.9 & -166.0 & -122.6 & -78.8 \\
\hline $\begin{array}{ll}\mathrm{e}^{\mathrm{s}}=.6 & \mathrm{e}_{\mathrm{r}}^{\mathrm{d}}=.2 \\
\mathrm{e}_{\mathrm{o}}^{\mathrm{d}}=.4 & \mathrm{e}_{\mathrm{c}}^{\mathrm{d}}=.2\end{array}$ & 655.1 & 655.1 & 655.1 & 655.1 & -208.9 & -166.0 & -122.6 & -78.8 \\
\hline $\begin{array}{ll}\mathrm{e}^{\mathrm{s}}=.7 & \mathrm{e}_{\mathrm{r}}^{\mathrm{d}}=.2 \\
\mathrm{e}_{\mathrm{o}}^{\mathrm{d}}=.4 & \mathrm{e}_{\mathrm{c}}^{\mathrm{d}}=.2\end{array}$ & 661.7 & 661.7 & 661.7 & 661.7 & -208.9 & -166.0 & -122.6 & -78.8 \\
\hline $\begin{array}{l}\text { Varying } e_{r}^{d} \\
\mathrm{e}^{\mathrm{s}}=.4 \quad \mathrm{e}_{\mathrm{r}}^{\mathrm{d}}=.0 \\
\mathrm{e}_{\mathrm{o}}^{\mathrm{d}}=.4 \quad \mathrm{e}_{\mathrm{c}}^{\mathrm{d}}=.2\end{array}$ & 641.8 & 641.8 & 641.8 & 641.8 & -208.9 & -166.0 & -122.6 & -78.8 \\
\hline $\begin{array}{ll}\mathrm{e}^{\mathrm{s}}=.4 & \mathrm{e}_{\mathrm{r}}^{\mathrm{d}}=.1 \\
\mathrm{e}_{\mathrm{o}}^{\mathrm{d}}=.4 & \mathrm{e}_{\mathrm{c}}^{\mathrm{d}}=.2\end{array}$ & 641.8 & 641.8 & 641.8 & 641.8 & -208.9 & -166.0 & -122.6 & -78.8 \\
\hline $\begin{array}{ll}\mathrm{e}^{\mathrm{s}}=.4 & \mathrm{e}_{\mathrm{r}}^{\mathrm{d}}=.3 \\
\mathrm{e}_{\mathrm{o}}^{\mathrm{d}}=.4 & \mathrm{e}_{\mathrm{c}}^{\mathrm{d}}=.2\end{array}$ & 641.8 & 641.8 & 641.8 & 641.8 & -208.9 & -166.0 & -122.6 & -78.8 \\
\hline $\begin{array}{ll}\mathrm{e}^{\mathrm{s}}=.4 & \mathrm{e}_{\mathrm{r}}^{\mathrm{d}}=.4 \\
\mathrm{e}_{\mathrm{o}}^{\mathrm{d}}=.4 & \mathrm{e}_{\mathrm{c}}^{\mathrm{d}}=.2\end{array}$ & 641.8 & 641.8 & 641.8 & 641.8 & -208.9 & -166.0 & -122.6 & -78.8 \\
\hline
\end{tabular}




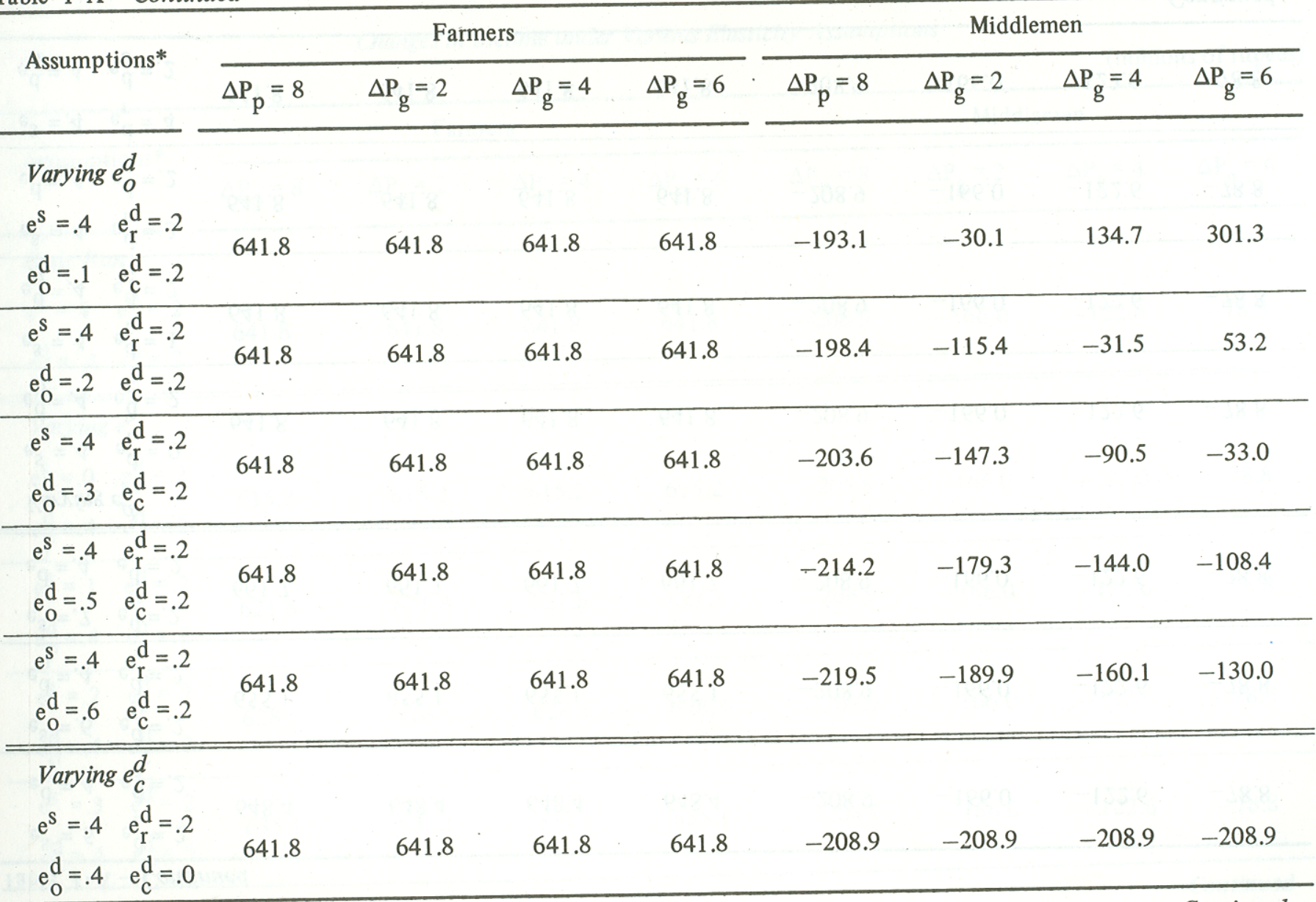

Table 1-A-Continued

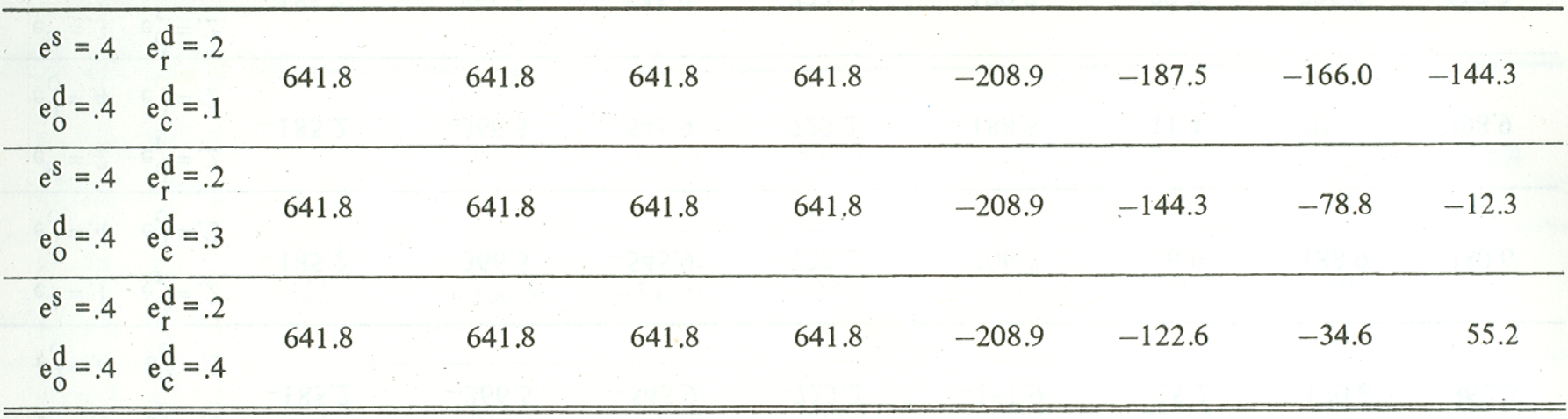

\section{Low Variant}

$\mathrm{e}^{\mathrm{s}}=.0 \quad \mathrm{e}_{\mathrm{r}}^{\mathrm{d}}=.0$

$e_{0}^{d}=.1 \quad e_{c}^{d}=.0$

615.2

615.2

615.2

615.2

$-193.1$

$-193.1$

$-193.1$

$-193.1$

\section{High Variant}

$\mathrm{e}^{\mathrm{s}}=.7 \quad \mathrm{e}_{\mathrm{r}}^{\mathrm{d}}=.5$

$\mathrm{e}_{\mathrm{o}}^{\mathrm{d}}=.6 \quad \mathrm{e}_{\mathrm{c}}^{\mathrm{d}}=.5$

661.7

661.7

661.7

661.7

$-219.5$

$-145.1$

$-68.9$

9.0

*The following initial values of the variables were used:

$$
\begin{array}{lllll}
P_{p}=37 & P_{c}=36 & P_{g}=32 & P_{0}=57 & P_{i}=56 \\
Q_{p}=2.825 & Q_{c}=3.35 & Q_{g}=1.1 & Q_{0}=1.725 & Q_{i}=2.25
\end{array}
$$




\begin{tabular}{|c|c|c|c|c|c|c|c|c|}
\hline \multirow{2}{*}{ Assumptions* } & \multicolumn{4}{|c|}{ Consumers } & \multicolumn{4}{|c|}{ Government } \\
\hline & $\Delta \mathrm{P}_{\mathrm{p}}=8$ & $\Delta P_{g}=2$ & $\Delta P_{g}=4$ & $\Delta P_{g}=6$ & $\Delta \mathrm{P}_{\mathrm{p}}=8$ & $\Delta P_{g}=2$ & $\Delta P_{g}=4$ & $\Delta P_{g}=6$ \\
\hline Basic Run & & & & & & & & \\
\hline $\begin{array}{ll}\mathrm{e}^{\mathrm{s}}=.4 & \mathrm{e}_{\mathrm{r}}^{\mathrm{d}}=.2 \\
\mathrm{e}_{\mathrm{o}}^{\mathrm{d}}=.4 & \mathrm{e}_{\mathrm{c}}^{\mathrm{d}}=.2\end{array}$ & -185.2 & -366.5 & -545.9 & -723.2 & -151.9 & 48.0 & 243.8 & 435.5 \\
\hline
\end{tabular}

Varying $e^{S}$

$\mathrm{e}^{\mathrm{s}}=.1 \quad \mathrm{e}_{\mathrm{r}}^{\mathrm{d}}=$ $-185.2-366.5$

$-545.9$

$-723.2$

$-151.9$

$-25.2$

170.6

362.3

$\mathrm{e}_{\mathrm{o}}^{\mathrm{d}}=.4 \quad \mathrm{e}_{\mathrm{c}}^{\mathrm{d}}=.2$

$\mathrm{e}^{\mathrm{s}}=.1 \quad \mathrm{e}_{\mathrm{r}}^{\mathrm{d}}=.2$

$-185.2$

$-366.5 \quad-545.9$

$-723.2$

$-206.7$

$-6.9$

188.9

380.6

$\mathrm{e}_{\mathrm{o}}^{\mathrm{d}}=.4 \quad \mathrm{e}_{\mathrm{c}}^{\mathrm{d}}=.2$

$\mathrm{e}^{\mathrm{s}}=.2 \quad \mathrm{e}_{\mathrm{r}}^{\mathrm{d}}=.2$

$-185.2$

$-366.5$

$-545.9$

$-723.2$

$-188.5$

11.4

207.2

398.9

$\mathrm{e}_{\mathrm{o}}^{\mathrm{d}}=.4 \quad \mathrm{e}_{\mathrm{c}}^{\mathrm{d}}=.2$

$\mathrm{e}^{\mathrm{s}}=.3 \quad \mathrm{e}_{\mathrm{r}}^{\mathrm{d}}=.2$

$\mathrm{e}_{\mathrm{o}}^{\mathrm{d}}=.4 \quad \mathrm{e}_{\mathrm{c}}^{\mathrm{d}}=.2$

$\mathrm{e}^{\mathrm{S}}=.5 \quad \mathrm{e}_{\mathrm{r}}^{\mathrm{d}}=.2$

$e_{0}^{d}=.4 \quad e_{c}^{d}=.2$

$\mathrm{e}^{\mathrm{s}}=.6 \quad \mathrm{e}_{\mathrm{r}}^{\mathrm{d}}=.2$

$e_{0}^{d}=.4 \quad e_{c}^{d}=.2$

$\mathrm{e}^{\mathrm{s}}=.7 \quad \mathrm{e}_{\mathrm{r}}^{\mathrm{d}}=.2$

$\mathrm{e}_{\mathrm{o}}^{\mathrm{d}}=.4 \quad \mathrm{e}_{\mathrm{c}}^{\mathrm{d}}=.2$

\section{Varying $e_{r}^{d}$}

$\mathrm{e}^{\mathrm{S}}=.4 \quad \mathrm{e}_{\mathrm{r}}^{\mathrm{d}}=.0$

$\mathrm{e}_{0}^{\mathrm{d}}=.4 \quad \mathrm{e}_{\mathrm{c}}^{\mathrm{d}}=.2$

$-185.2$

$-367.6$

$-549.9$

$-732.3$

$-151.9$

27.7

207.3

386.9

$\mathrm{e}^{\mathrm{s}}=.4 \quad \mathrm{e}_{\mathrm{r}}^{\mathrm{d}}=.1$

$\mathrm{e}_{\mathrm{o}}^{\mathrm{d}}=.4 \quad \mathrm{e}_{\mathrm{c}}^{\mathrm{d}}=.2$

$-185.2$

$\mathrm{e}^{\mathrm{s}}=.4 \quad \mathrm{e}_{\mathrm{r}}^{\mathrm{d}}=.3$

$\mathrm{e}_{\mathrm{o}}^{\mathrm{d}}=.4 \quad \mathrm{e}_{\mathrm{c}}^{\mathrm{d}}=.2$

$-185.2$

$\mathrm{e}^{\mathrm{s}=.4} \quad \mathrm{e}_{\mathrm{r}}^{\mathrm{d}}=.4$

$\mathrm{e}_{\mathrm{o}}^{\mathrm{d}}=.4 \quad \mathrm{e}_{\mathrm{c}}^{\mathrm{d}}=.2$ 
Assumptions*

\begin{tabular}{llll}
\hline$\Delta \mathrm{P}_{\mathrm{p}}=8$ & $\Delta \mathrm{P}_{\mathrm{g}}=2$ & $\Delta \mathrm{P}_{\mathrm{g}}=4$ & $\Delta \mathrm{P}_{\mathrm{g}}=6$
\end{tabular}

Government

Varying $e_{o}^{d}$

$\mathrm{e}^{\mathrm{s}}=.4 \quad \mathrm{e}_{\mathrm{r}}^{\mathrm{d}}=.2$

$\mathrm{e}_{\mathrm{O}}^{\mathrm{d}}=.1 \quad \mathrm{e}_{\mathrm{c}}^{\mathrm{d}}=.2$

$-187.2$

$-368.5$

$-547.9$

$-725.2$

$-162.8$

37.0

232.8

424.5

$\mathrm{e}^{\mathrm{s}}=.4 \quad \mathrm{e}_{\mathrm{r}}^{\mathrm{d}}=.2$

$\mathrm{e}_{\mathrm{O}}^{\mathrm{d}}=.2 \quad \mathrm{e}_{\mathrm{c}}^{\mathrm{d}}=.2$

$-367$

$-724.5$

$-151.9$

40.7

236.4

428.1

$\mathrm{e}^{\mathrm{s}}=.4 \quad \mathrm{e}_{\mathrm{r}}^{\mathrm{d}}=.2$

$\mathrm{e}_{\mathrm{o}}^{\mathrm{d}}=.3 \quad \mathrm{e}_{\mathrm{c}}^{\mathrm{d}}=.2$

$-185.5$

$-367.2$

$-546.5$

$-723.8$

$-155.5$

44.3

240.1

431.8

$\mathrm{e}^{\mathrm{s}}=.4 \quad \mathrm{e}_{\mathrm{r}}^{\mathrm{d}}=.2$

$\mathrm{e}_{\mathrm{o}}^{\mathrm{d}}=.5 \quad \mathrm{e}_{\mathrm{c}}^{\mathrm{d}}=.2$

$$
-184.5
$$

$-365.9$

$-545.2-722.5$

$-148.3$

51.6

247.4

439.2

$\mathrm{e}^{\mathrm{s}}=.4 \quad \mathrm{e}_{\mathrm{r}}^{\mathrm{d}}=.2$

$\mathrm{e}_{\mathrm{o}}^{\mathrm{d}}=.6 \quad \mathrm{e}_{\mathrm{c}}^{\mathrm{d}}=.2$

$-183.9$

$-365.2-544.6$

$-721.9$

$-144.6$

55.3

251.1

442.9

Varying $e_{c}^{d}$

$\mathrm{e}^{\mathrm{s}}=.4 \quad \mathrm{e}_{\mathrm{r}}^{\mathrm{d}}=.2$

$e_{0}^{d}=.4 \quad e_{c}^{d}=.0$

$-185.2$

443.9

\section{$y$}

Table 1-B - Continued

\begin{tabular}{|c|c|c|c|c|c|c|c|c|}
\hline $\begin{array}{ll}\mathrm{e}^{\mathrm{s}}=.4 & \mathrm{e}_{\mathrm{r}}^{\mathrm{d}}=.2 \\
\mathrm{e}_{\mathrm{o}}^{\mathrm{d}}=.4 & \mathrm{e}_{\mathrm{c}}^{\mathrm{d}}=.1\end{array}$ & -185.2 & -366.5 & -545.9 & -723.2 & -151.9 & 49.4 & 246.6 & 439.7 \\
\hline $\begin{array}{ll}\mathrm{e}^{\mathrm{s}}=.4 & \mathrm{e}_{\mathrm{r}}^{\mathrm{d}}=.2 \\
\mathrm{e}_{\mathrm{o}}^{\mathrm{d}}=.4 & \mathrm{e}_{\mathrm{c}}^{\mathrm{d}}=.3\end{array}$ & -185.2 & -366.5 & -545.9 & -723.2 & -151.9 & 46.4 & 241.0 & 431.3 \\
\hline $\begin{array}{ll}\mathrm{e}^{\mathrm{s}}=.4 & \mathrm{e}_{\mathrm{r}}^{\mathrm{d}}=.2 \\
\mathrm{e}_{\mathrm{o}}^{\mathrm{d}}=.4 & \mathrm{e}_{\mathrm{c}}^{\mathrm{d}}=.4\end{array}$ & -185.2 & -366.5 & -545.9 & -723.2 & -151.9 & 45.2 & 238.2 & 427.1 \\
\hline
\end{tabular}

\section{Low Variant}

$\mathrm{e}^{\mathrm{s}}=.0 \quad \mathrm{e}_{\mathrm{r}}^{\mathrm{d}}=.0$

$e_{0}^{d}=.1 \quad e_{c}^{d}=.0$

$-369.5$

$-551.9$

$-734.3$

$-235.9$

$-53.5$

128.8

311.2

\section{High Variant}

$\mathrm{e}^{\mathrm{s}}=.7 \quad \mathrm{e}_{\mathrm{r}}^{\mathrm{d}}=.5$

$\mathrm{e}_{\mathrm{O}}^{\mathrm{d}}=.6 \quad \mathrm{e}_{\mathrm{c}}^{\mathrm{d}}=.5$

$-183.9$

$\begin{array}{lll}-363.7 & -538.5 & -708.2\end{array}$

$-89.8$

136.4

352.4

558.3

${ }^{*}$ The following initial values of the variables were used:

$$
\begin{array}{lllll}
P_{p}=37 & P_{c}=36 & P_{g}=32 & P_{0}=57 & P_{i}=56 \\
Q_{p}=2.825 & Q_{c}=3.35 & Q_{g}=1.1 & Q_{0}=1.725 & Q_{i}=2.25
\end{array}
$$




\begin{tabular}{|c|c|c|c|c|c|c|c|c|}
\hline \multirow{2}{*}{ Assumptions* } & \multicolumn{4}{|c|}{ Farmers } & \multicolumn{4}{|c|}{ Middlemen } \\
\hline & $\Delta \mathrm{P}_{\mathrm{p}}=8$ & $\Delta \mathrm{P}_{\mathrm{g}}=2$ & $\Delta \mathrm{P}_{\mathrm{g}}=4$ & $\Delta P_{g}=6$ & $\Delta P_{p}=8$ & $\Delta \mathrm{P}_{\mathrm{g}}=2$ & $\Delta P_{g}=4$ & $\Delta P_{g}=6$ \\
\hline No Change & 641.8 & 641.8 & 641.8 & 641.8 & -208.9 & -166.0 & -122.6 & -78.8 \\
\hline$P_{0}=65$ & 641.8 & 641.8 & 641.8 & 641.8 & -215.6 & -165.3 & -114.6 & -63.4 \\
\hline$P_{0}=50$ & 641.8 & 641.8 & 641.8 & 641.8 & -201.3 & -164.8 & -127.9 & -90.6 \\
\hline $\begin{array}{l}\mathrm{Q}_{\mathrm{p}}=3.0 \mathrm{Q}_{\mathrm{c}}=3.3 \\
\mathrm{Q}_{\mathrm{o}}=1.9 \mathrm{Q}_{\mathrm{i}}=2.2\end{array}$ & 681.5 & 681.5 & . 681.5 & 681.5 & -230.1 & -182.8 & -135.0 & -86.8 \\
\hline
\end{tabular}

*The elasticity assumptions are $\mathrm{e}^{\mathrm{s}}=.4, \mathrm{e}_{\mathrm{r}}^{\mathrm{d}}=.2, \mathrm{e}_{\mathrm{o}}^{\mathrm{d}}=.4, \mathrm{e}_{\mathrm{c}}^{\mathrm{d}}=.2$

Note: The initial values of the variables are as in Table 1 except where otherwise specified.

Table 2-B

Changes in Incomes under Differing Initial Values of Variables

(millions of rupees)

\begin{tabular}{|c|c|c|c|c|c|c|c|c|}
\hline \multirow{2}{*}{ Assumptions* } & \multicolumn{4}{|c|}{ Consumers } & \multicolumn{4}{|c|}{ Government } \\
\hline & $\Delta P_{p}=8$ & $\Delta P_{g}=2$ & $\Delta P_{g}=4$ & $\Delta P_{g}=6$ & $\Delta \mathrm{P}_{\mathrm{p}}=8$ & $\Delta P_{g}=2$ & $\Delta P_{g}=4$ & $\Delta P_{g}=6$ \\
\hline No Change & -185.2 & -366.5 & -545.9 & -723.2 & -151.9 & 48.0 & 243.8 & 435.5 \\
\hline$P_{0}=65$ & -185.2 & -366.9 & -546.2 & -723.5 & -153.7 & 46.2 & 242.0 & 433.7 \\
\hline$P_{0}=50$ & -184.8 & -366.2 & -545.5 & -722.8 & -149.9 & 50.0 & 245.8 & 437.6 \\
\hline $\begin{array}{l}\mathrm{Q}_{\mathrm{p}}=3.0 \mathrm{Q}_{\mathrm{c}} \\
\mathrm{Q}_{\mathrm{O}}=1.9 \mathrm{Q}_{\mathrm{i}}=\end{array}$ & $.^{3}-204.0$ & -382.6 & -559.3 & -733.9 & -145.9 & 50.7 & 243.2 & 431.8 \\
\hline
\end{tabular}

*The elasticity assumptions are $\mathrm{e}^{\mathrm{s}}=.4, \mathrm{e}_{\mathrm{r}}^{\mathrm{d}}=.2, \mathrm{e}_{\mathrm{o}}^{\mathrm{d}}=.4, \mathrm{e}_{\mathrm{c}}^{\mathrm{d}}=.2$

Note: The initial values of the variables are as in Table 1 except where otherwise specified. 
far as he is a consumer of wheat for seed purposes or acts as a middleman when he stores wheat. However, the sheer magnitude of the primary gain highlights the fact that it is the group of farmers that stands to gain considerably from an increase in procurement price at the expense of the rest of the society.

(ii) The reader is reminded that the price changes are taken sequentially. Thus, the column of figures below $\Delta \mathrm{P}_{\mathrm{g}}=2$, for example, shows the aggregate effect of raising procurement price by Rs. 8 /maund and raising the issue price by Rs. 2/per maund.

(iii) Only the consumers in the open market lose by an increase in procurement price; ration shop consumers are unaffected. Conversely, only the ration shop consumers lose by an increase in the issue price. In Tables 1 and 2, the two effects are aggregated. However, the reader who wishes to see the effect on only the ration shop consumer simply has to subtract the elements of the column $\Delta \mathrm{P}_{\mathrm{p}}=8$ from the elements of columns $\Delta \mathrm{P}_{\mathrm{g}}=2,4$ and 6 to obtain the desired loss.

(iv) The results are fairly insensitive to changes in both parameters and variable values. For example, if the total production is 8.8 million tons instead of the estimated 8.1 million tons, the marketable surplus increases to 3.0 million tons and the profits to farmers to Rs. 681.8 million tons - an increase of less than 7 percent. The notable exception to this statement is the change in government income which is quite sensitive to a change in the elasticity of marketable surplus.

(v) As long as the demand elasticity of ration shop wheat is not zero and imports are positive, the gain to government from an increase in issue price is greater than the loss to consumers. Furthermore, middlemen also gain from an increase in issue price whereas farmers are unaffected. On efficiency ${ }^{6}$ grounds alone, it would be better to raise the issue price. However, raising the issue price leads to a loss to consumers of ration shop wheat, i.e. to the relatively poor consumers. On equity grounds, increasing the issue price may not be justifiable since income cannot readily be redistributed. The issue, then, is whether an increase of Rs. $200(151.9+48.0)$ million in government income, coupled with an increase of Rs. 43 (208.9-166.0) million in middlemen incomes, more than offsets a Rs. 181 (366.5 - 185.2) million loss to ration shop consumers.

\section{CONCLUSIONS AND POLICY IMPLICATIONS}

One of the main contributions of this paper is the measurement of the gains and losses to our interest groups from the announced increase in procurement price of wheat, whether or not this is accompanied by a hike in the issue price. The farmers stand to gain over Rs. 600 million from the procurement price increase. The

${ }^{6}$ Efficiency here is defined in the pareto optimal sense of having equality between the consumer price, $\mathrm{P}_{\mathrm{c}}$ (the marginal rate of substitution between wheat and rupees), the produce price, $P_{P}$ (the marginal rate of transformation in domestic production), and the international

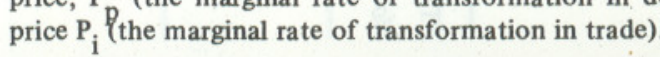

gain occurs at the expense of middlemen, consumers of open market wheat and the government. The higher the elasticity of marketable surplus, the smaller the loss to the government. An optimistic value of 0.7 implies that the government loses only about Rs. 90 million whereas a pessimistic value of 0.0 raises the government subsidy by. Rs. 236 million. Middlemen and open-market consumers tend to lose about Rs. 200 million each for a plausible range of elasticities.

An increase in issue price is better for the country from an efficiency point of view. With this policy, farmers are unaffected and middlemen gain a little while the government gains more than the loss to consumers. However, raising of issue price causes a substantial loss to the relatively poor ration shop consumer.

The most efficient solution would be to equate both the consumption and procurement prices with the international price, thus eliminating price consumption and production inefficiencies. However, this extreme policy cannot be carried out overnight and may not even be desirable on account of its adverse impact on poorer ration shop consumers (to say nothing of subsidies on inputs and other market inefficiencies which change the optimal solution). If income could be costlessly and effectively distributed, this policy would clearly be optimal. However, since taxation is costly and ineffective and there is virtually no way for the government to give transfers to the poor other than through lowered prices of essential commodities, one now has to trade off a smaller rupee loss of Rs. 181 million to the poor consumers, with a gain of Rs. 200 million to the government and Rs. 43 million to the middlemen.

Similarly, efficiency in trade requires that the domestic price be set equal to the international price. Again, since the government cannot effectively tax farmers for their windfall gain and it is not feasible to set up a scheme where the incremental production is paid Rs. 56/maund (the international price) while old production is paid at the old price, this policy is not very practical.

Thus, depending on one's preferences, and given the constraints on redistribution, one might well prefer a non-pareto optimal to a pareto optimal solution. This paper clearly spells out the magnitudes of the efficiency losses by adopting a nonpareto optimal solution.

\section{Postscript}

The reader will be interested to know that soon after the paper was first submitted, the government raised the issue price to equal the new procurement price. 
Size of the Open Market

\begin{tabular}{ccccc}
\hline $\begin{array}{c}\text { Farm Size } \\
\text { (acres) }\end{array}$ & $\begin{array}{c}\text { \% of area } \\
\text { under wheat }\end{array}$ & $\begin{array}{c}\text { Wheat output } \\
\text { (million tons) }\end{array}$ & $\begin{array}{c}\text { \% of wheat } \\
\text { marketed }\end{array}$ & $\begin{array}{c}\text { Marketable } \\
\text { surplus }\end{array}$ \\
\hline (1) & $(2)$ & $(3)$ & $(4)$ & $(5)$ \\
\hline Less than & & & & \\
12.5 & 38.62 & 3.15 & 29 & 0.914 \\
12.5 to 25 & 29.46 & 2.41 & 35 & 0.844 \\
25 to 50 & 17.57 & 1.43 & 37 & 0.529 \\
59 and above & 14.35 & 1.17 & 46 & 0.538 \\
\hline
\end{tabular}

Source: Agricultural Census of Pakistan, 1972, for Col. 2; [1] for Col. 4.

Note: 1. Wheat output (Col. 3) is based on the assumption of same average yields on different farm sizes.

2. Figures in Col. 4 allow for loss due to seeds and wastage.

The quantity of wheat marketed is 2.825 million tons with a total production of 8.16 million tons. With the government's procurement equal to 1.1 million tons, the size of the open market is 1.725 million tons.

$$
\text { To Show } \Delta \mathrm{P}_{\mathrm{o}}=1 / 2 \Delta \mathrm{P}_{\mathrm{p}}
$$

Appendix II

Let the equation to the demand curve be

$$
Q=f(P) \text { so that we have }
$$$$
P=f^{-1}(Q)=g(Q) \text {. }
$$

The slope of the demand curve is

$$
\frac{d_{p}}{d Q}=g^{\prime}(Q) \text {. }
$$

Since Revenue $\quad=P Q$

$$
=\mathrm{g}(\mathrm{Q}) \mathrm{Q} \text {, }
$$

Marginal revenue $=g^{\prime}(Q)+Q^{\prime}(Q)$

and the slope of the marginal revenue curve is

$$
\begin{aligned}
\frac{d M R}{d Q} & =g^{\prime}(Q)+Q g^{\prime \prime}(Q)+Q g^{\prime \prime}(Q)+g^{\prime}(Q) \\
& =2 g^{\prime}(Q)+Q g^{\prime \prime}(Q)
\end{aligned}
$$

If the relevant section of the demand curve is linear, $g^{\prime \prime}(Q)=0$ and, hence the slope of the MR curve is twice the slope of the demand curve.

In Fig. 2, the slope of DF is half that of $A C$ from the result above. Since $\mathrm{BC}=\mathrm{EF}, \mathrm{DE}=1 / 2 \mathrm{AB}$

Thus, if the section of the demand curve where that is operative is linear, a change of $\Delta \mathrm{P}_{\mathrm{p}}$ in the procurement price causes an increase in the open market price of $1 / 2 \Delta \mathrm{P}_{\mathrm{p}}$ 
To Derive Expressions for $\mathrm{Q}_{\mathrm{O}}$ and $\mathrm{P}_{\mathrm{O}}$

Fig. 5 is a simplified linear version of Fig. 4

in $\mathrm{P}$ shifts the demand curve of open market wheat horizontally an amount equal to $2 \mathrm{k}$ to $\mathrm{D}^{\prime} \mathrm{F}^{\prime}$ where

$2 k=e_{c}^{d} \frac{\Delta P_{c}}{P_{c}} Q_{O}$ from the definition of $e_{c}^{d}$

Since $\mathrm{OR}^{\prime}=\frac{1}{2} \mathrm{OF}^{\prime}, \mathrm{DA}=\frac{1}{2} \mathrm{DB}$ from similar triangles.

Since DA is parallel to $\mathrm{XY}$ and $\mathrm{D}^{\prime} \mathrm{R}^{\prime}$ is parallel to $\mathrm{DX}, \mathrm{DA}=\mathrm{XY}$ and so the horizontal shift in output is half the horizontal shift in demand

$$
\Delta Q_{O}=k=\frac{e_{c}^{d} \Delta P_{c}}{2 P_{c}} Q_{0} .
$$

The increase in price is $\Delta \mathrm{P}_{\mathrm{O}}$, which is equal to y in Fig. 5 .

$$
\begin{aligned}
& \text { Since } y=k \frac{d P}{d Q} \\
& \text { where } \frac{d P}{d Q}=\frac{d P_{o}}{d Q_{0}} \text {, } \\
& \mathrm{e}_{\mathrm{o}}^{\mathrm{d}}=\frac{\mathrm{dQ}_{\mathrm{o}}}{\mathrm{dP}_{\mathrm{O}}} \frac{\mathrm{P}_{\mathrm{o}}}{\mathrm{Q}_{\mathrm{O}}}, \\
& y=\frac{k P_{0}}{Q_{0} e_{0}^{d}} \text {, and, hence, } \\
& \Delta \mathrm{P}_{\mathrm{O}}=\frac{\mathrm{e}_{\mathrm{c}}^{\mathrm{d}} \Delta \mathrm{P}_{\mathrm{c}}}{2 \mathrm{e}_{\mathrm{O}}^{\mathrm{d}} \mathrm{P}_{\mathrm{c}}} \mathrm{P}_{\mathrm{O}}
\end{aligned}
$$




\section{NOTATION}
$P_{p} \quad$ Procurement price of wheat (Rs. 37/maund)
$P_{c} \quad$ Retail price of ration shop wheat (Rs. 36/maund)
$\mathrm{P}_{\mathrm{g}} \quad$ Issue price of wheat - price at which the government sells to the mill (Rs. 32/maund)
$P_{0} \quad$ Average retail price of open market wheat (Rs. 57/maund)
$P_{i} \quad$ Price of imported wheat (Rs. 56/maund)
$\mathrm{Q}_{\mathrm{p}} \quad$ Total marketable supply of wheat (2.825 million tons)
$Q_{c} \quad$ Quantity of wheat sold via ration shops - sum of government procured and imported wheat (3.35 million tons)

$Q_{g} \quad$ Quantity of wheat procured by the government domestically (1.1 million tons)

$\mathrm{Q}_{\mathrm{o}} \quad$ Quantity of wheat sold in the open market $\left(\mathrm{Q}_{\mathrm{p}}-\mathrm{Q}_{\mathrm{g}}\right)$

$\mathrm{Q}_{\mathrm{i}} \quad$ Quantity of imported wheat (2.25 million tons)

$\mathrm{e}^{\mathrm{s}} \quad$ Elasticity of marketable surplus

$\mathrm{e}_{\mathrm{r}}^{\mathrm{d}} \quad$ Demand elasticity of ration shop wheat

$\mathrm{e}_{\mathrm{o}}^{\mathrm{d}} \quad$ Demand elasticity of open market wheat

$e_{c}^{d} \quad$ Cross elasticity of open market wheat with respect to ration shop wheat.

(Please note that all $\Delta \mathrm{s}$ are assumed to be positive by convention.)

\section{REFERENCES}

1. Micas Associates Ltd. A Study of Problems Associated with Procurement, Storage and Distribution of Wheat. Vol. I. Karachi. March 1976.

2. Qureshi, Sarfraz K. "Price Responsiveness of Marketed Surplus of Wheat in Pakistan”. Pakistan Development Review. Vol. XIII, No. 2. Summer 1974. 


\section{NOTATION}

$P_{p} \quad$ Procurement price of wheat (Rs. 37/maund)

$P_{c} \quad$ Retail price of ration shop wheat (Rs. 36/maund)

$\mathrm{P}_{\mathrm{g}} \quad$ Issue price of wheat - price at which the government sells to the mill (Rs. 32/maund)

$P_{0} \quad$ Average retail price of open market wheat (Rs. 57/maund)

$P_{i} \quad$ Price of imported wheat (Rs. 56/maund)

$\mathrm{Q}_{\mathrm{p}} \quad$ Total marketable supply of wheat (2.825 million tons)

$Q_{c} \quad$ Quantity of wheat sold via ration shops - sum of government procured and imported wheat ( 3.35 million tons)

$Q_{g} \quad$ Quantity of wheat procured by the government domestically (1.1 million tons)

$Q_{0} \quad$ Quantity of wheat sold in the open market $\left(Q_{p}-Q_{g}\right)$

$\mathrm{Q}_{\mathrm{i}} \quad$ Quantity of imported wheat (2.25 million tons)

$\mathrm{e}^{\mathrm{S}} \quad$ Elasticity of marketable surplus

$\mathrm{e}_{\mathrm{r}}^{\mathrm{d}} \quad$ Demand elasticity of ration shop wheat

$e_{0}^{d} \quad$ Demand elasticity of open market wheat

$e_{c}^{d} \quad$ Cross elasticity of open market wheat with respect to ration shop wheat.

(Please note that all $\Delta \mathrm{s}$ are assumed to be positive by convention.)

\section{REFERENCES}

1. Micas Associates Ltd. A Study of Problems Associated with Procurement, Storage and Distribution of Wheat. Vol. I. Karachi. March 1976.

2. Qureshi, Sarfraz K. "Price Responsiveness of Marketed Surplus of Wheat in Pakistan”. Pakistan Development Review. Vol. XIII, No. 2. Summer 1974. 